\title{
Past and Present: A Reflection of Professional Judgment of CPA - A Case Study of "Southern Securities"
}

\author{
Yongchen $\mathrm{Li}^{1 \text {, a }}$, Jiahui Guo ${ }^{2, \mathrm{~b}}$ \\ ${ }^{1}$ School of Economic Management, North China Electric Power University, Baoding 071000, China \\ ${ }^{2}$ School of Economic Management, North China Electric Power University, Baoding 071000, China \\ alycyongchen@163.com, bjiahuihbu@163.com
}

Keywords: Auditing; CPA; impairment provision; standard of professional judgment

\begin{abstract}
The case of Southern Securities has been past for over ten years, Analysis of the case of the Southern Securities was always focused on the impairment provision and related issues. However, few people studied about how to deal with the auditing consequence of the case, because eight major shareholders used different proportions of impairment provision, while CPAs agreed with every shareholder's accounting treatment. This paper analyzes the case of Southern Securities from the perspective of audit. To get further discussion, we will seek why CPA adopted different standards of professional judgment on the same event, and analysis about countermeasures so as to provide reference for the future study of CPA's professional judgment.
\end{abstract}

\section{Introduction}

Southern Securities was set up in 1992 in Shenzhen, it is one of the largest security companies at that time. It was operating well at first, but with the time flies, its development declined heavily. In 2004, The China securities regulatory commission and Shenzhen government decided to take over Southern Securities. This event has a significant impact on the eight largest shareholders of the Southern securities. At the end of 2003, eight shareholders of the South Securities planned to raise the provision for impairment. However, the proportions of provision about the impairment of their respective investments were significantly different; the highest reached $100 \%$, while the lowest is only 15\%. Surprisingly, in the face of the same event, in the 2003 annual audit report of the eight shareholders, there are six to get the standard views of the audit report. In the same event, the differences between proportions of shareholders are so large. This case made us wondering why CPAs used different professional judgment standard in face of the same event.

\section{Cause analysis}

Through the analysis of facts and relevant data, we found the reasons that CPA did not have different answers for eight shareholders about the impairment are as follows:

First, the amount of impairment provision is affected by the will of the management layers. The audit opinion is the result of the negotiation between the certified public accountants and the audited entity. We can look at the relevant impact from the next table, say, the influence of different amount of impairment provision on the profit of enterprises. 
Table 1 Proportion of provision for impairment

\begin{tabular}{cccccc}
\hline Name & $\begin{array}{c}\text { Final } \\
\text { investment } \\
\text { balance }\end{array}$ & $\begin{array}{c}\text { Net profit } \\
\text { of the } \\
\text { year }\end{array}$ & $\begin{array}{c}\text { Provision } \\
\text { for }\end{array}$ & $\begin{array}{c}\text { Proportion of } \\
\text { provision } \\
\text { for } \\
\text { impairment }\end{array}$ & $\begin{array}{c}\text { Net profit } \\
\text { ifter full } \\
\text { provision }\end{array}$ \\
\hline $\begin{array}{c}\text { Shanghai } \\
\text { Automobile }\end{array}$ & 39600 & 148889 & 39600 & $100 \%$ & 148889 \\
Beijing Capital & 39600 & 40352 & 5940 & $15 \%$ & 6692 \\
$\begin{array}{c}\text { ZSEPC } \\
\text { Handan Iron }\end{array}$ & 22000 & 60928 & 18015 & $82 \%$ & 56943 \\
$\begin{array}{c}\text { \&Steel } \\
\text { Winner }\end{array}$ & 11000 & 62647 & 6791 & $62 \%$ & 58438 \\
$\begin{array}{c}\text { NEPTUNUS } \\
\text { ZYYQ }\end{array}$ & 7719 & 4029 & 2316 & $30 \%$ & -1374 \\
$\begin{array}{c}\text { CRBC } \\
\text { International }\end{array}$ & 4950 & 52165 & 2723 & $55 \%$ & 49938 \\
\hline
\end{tabular}

Through the table we can find that if the provision for impairment is $100 \%$, the major profit of shareholders at that year will be affected. For Beijing Capital, its net profit will lose $82 \%$ if it used full provision. For Winner, its losses will be further expanded; this would be a big blow to the group, for it had been lost profits for two years. However, for company like Shanghai Auto, the operating conditions will not be influenced even by having a 100\% provision.

Second, the certified public accountants have no uniform standards on the level of significance in practice. In general, the level of importance of the enterprise can be formulated as a percentage of fixed indicators. Here, we choose the operating profit of $5 \%$ as a reference standard of the level of importance.

Table 2 Impairment provision and importance level

\begin{tabular}{ccccc}
\hline Name & $\begin{array}{c}\text { Operating profit } \\
\text { before tax }\end{array}$ & $\begin{array}{c}\text { 5\% of Operating profit } \\
\text { before tax }\end{array}$ & $\begin{array}{c}\text { Investment } \\
\text { balance }\end{array}$ & $\begin{array}{c}\text { Provision } \\
\text { for }\end{array}$ \\
\hline $\begin{array}{c}\text { Shanghai } \\
\text { Automobile }\end{array}$ & 82404715.3 & 4120235.77 & 39600 & 39600 \\
Beijing Capital & 41137642.38 & 2056882.12 & 39600 & 5940 \\
ZSEPC & 981036628.3 & 49051831.42 & 22000 & 18015 \\
Handan & 1070858973 & 53542948.65 & 11000 & 6791 \\
Iron\&Steel & -249643330 & -12482166.5 & 8334 & 7501 \\
Winner & -32605661.06 & -1630283.05 & 7719 & 2316 \\
NEPTUNUS & 69193526.87 & 3459676.34 & 4950 & 2723 \\
ZYYQ & 34469723.2 & 1723486.16 & 3300 & 2316 \\
CRBC & & & & \\
International & & & & \\
\hline
\end{tabular}

From the above table we can see that if the pretax operating profit of 5\% was used as the level of importance of the standard, in addition to the two enterprises which pretax operating profit are negative numbers, this standard can have a great significance. In the auditing practice of certified public accountants, the importance level is still a relatively vague definition. This ambiguity is 
reflected in the choice of the standard of importance; the other is reflected in the selection of the level of importance, in the actual execution of the process, whether it is able to strictly definite the standard is still a problem.

Third, eight accounting firms are located in different regions of the country; there are differences in professional judgment or standard of practice. We can find that the major shareholders to audit the eight accounting firms are in six cities, across the south, the north and the central. And the sizes of the eight firms are also different, both from the Four Giant Accounting Firms and from the domestic accounting firms. Because different CPAs are not allowed to communicate with each other even for the same matter, it is very difficult for a certified public accountant to judge whether the impairment provision is in accordance with the reality, there is no objection to this matter. Similarly, these firms are different in size and strength. This is also the cause of the impairment provision is of great difference. That means in face with various enterprises, CPAs can all give them a standard conclusion of the audit report. This is consistent with previous studies, that is, in spite of the significant impact of the firm size on audit conclusion types, when considering the importance level and the firm size, it is found that there are differences in the level of importance of the firm in different scale. Large firms are more sensitive to errors, for example "giant four firms" are more likely to issue non-standard comments on the wrong statements.

\section{Results and countermeasure analysis}

In the previous studies, the scholars have made a research on the improvement of professional judgment of CPA, and the relevant conclusions are drawn. Ping $\mathrm{Xu}(2012)$ analyzed the factors that affect the professional judgment of CPA, and it is considered that the audit environment and the self-quality of certified public accountants are the two factors that influence CPA's professional judgment. Liying Dong(2009) analysis the CPA professional judgment and professional judgment mode, pointed out that to enhance the professional judgment ability of CPA needs to improve three points. First, the need of configure a reasonable professional structure of the audit team is invisible, the second is to deepen the construction of professional ethics, and the third is to improve the comprehensive ability of practicing personnel. Although the case of Southern Securities has been passed many years, its reflection of the relevant problems still exist, thus, we put forward the following measures:

First, from the perspective of the government and industry associations, it is necessary to strengthen the internal communication of the CPA industry, to promote the maturity of the CPA industry. Strengthen the communication within the industry can let the start-up phase accounting firm to modify its operation system and learn from the modes of major accounting firm. It can also promote the unity of evaluation criteria of different CPAs on the same matter, which makes the CPA's professional judgment more normative.

Second, from the perspective of the audited units, they should strengthen the internal control of enterprises to assist the audit of certified public accountants and optimize the objective environment of CPA audit. Because the certified public accountants should know the internal control of the audited units, that is, the control environment, the risk assessment process, the information system and the communication and the control activities. There is no doubt that if the internal controlling of the audit unit is perfect, the certified public accountant on the audited units can be more reliable, which is more conducive to the CPA's professional judgment, so that the audit results of Certified Public Accountants is more scientific and reasonable to accept.

Third, it is important to improve the system of laws, rules and regulations related to the professional judgment of the CPA. It can promote to ensure that the level of professional judgment of certified public accountants. At present, the Chinese Institute of certified public accountants is the industrial self-regulatory organization; it leads and standardizes the CPA industry. At present, there have has the normative documents of the accounting standard for certified public accountants, professional ethics and practice guidelines. And it provides professional technical advice for the CPAs. At the same time, the Chinese Institute of Certified Public Accountants is still conducting quality supervision and assessment of the accounting firm annually. But only by the execution of 
laws and regulations to form a uniform standard of judgement is relatively difficult, so industry self-regulatory organizations should improve communication system, and increase the specific implementation details, promoting the registration accountant industry standardization.

\section{Conclusion}

The case of Southern Securities has been passed for more than ten years, even though, the typical nature of the incident and the relevant issues which are discussed before are still having great significance. In the past, the researches of this event were usually focused on the exploration of impairment provision and surplus compensation. While from the perspective of the CPAs, there are few studied to learn about the auditing and professional judgment. And that's why we're here to analyze this event. Something must to be explained is that after 2006, the accounting standards has been changed, the long term equity investment impairment, which was originally proposed to be reversed, cannot be turned back now. This can to some extent explain the difference in the attitude of the eight shareholders of that time to prepare for impairment. The company which is in a good condition may tend to have a smooth and sustainable profits while poor operating-conditionenterprises are not capable of doing so. But even so, in this case, the management of the provision for impairment still has such a large subjective bias, facing with the same event, different stockholders used various accounting dealings, while CPAs cannot decide whether it is reasonable and they need a unite professional judgment standard. This phenomenon itself reflects the shortcomings of the CPA professional judgment. Through recent years of audit reports, we can find that this problem still exists. Professional judgment is still not able to have a unified, sound standards, this situation, if not be corrected, will seriously affect the progress and development of China's CPA industry.

\section{References}

[1]. Xiaojun Jiang, “On the difference of impairment provision and earnings management -- A Case Study on the Southern Securities.,” Time Finance pp. 79-80, August 2013.

[2]. Xuebin Zhao and Yajie Zhang. "Thinking on the provision of long term investment impairment for the shareholders of the South Securities”. Financial and Accounting, October 2011, pp.45-46.

[3]. Huangting Meng and Duolei Zhang, “The influence of long term equity investment impairment provision ratio on corporate profits -- Based on the consideration of Southern Securities administrative takeover case” Financial and Accounting,2012, pp. 17-19.

[4]. Yongchen $\mathrm{Li}$, "The social environment influence and management system arrangement of audit principle,” Friends of accounting. September 2010. .pp10-15

[5]. Qizhen Zhang, "Fuzziness of audit concept” Finance and Trade Research, June 2012. pp 45-47

[6]. Xiaoyan Xie and Hui Zhang, “CPA professional judgment based on risk oriented audit,” CPA of China, April 2012

[7]. Liying Dong and Lingling $\mathrm{Wu}$ "Research on the path of improving the professional judgment ability of CPA in China": Economy and management, December, 2014.

[8]. Ping Xu. Key factors of success or failure of audit. Communication of Finance and Accounting. February, 2012 